Covered in: ERIH PLUS, HeinOnline, CEEOL, Index Copernicus, CrossRef, CrossCheck, J-GATE, Google Scholar, Ideas RePeC, Econpapers, Socionet, KVK, WorldCat.

\section{About the Right to Same-Sex Marriage. Some \\ Considerations and Interpretations from the Constitutional Law Perspective}

\author{
Cătălina MITITELU1 \\ ${ }^{1}$ Ovidius University of Constanta, \\ Constanta, Romania, \\ ovidiustomis@yahoo.co.uk
}

Abstract: Both Natural law (Jus naturale) and Roman law (Jus romanum), and the main international instruments - (the Universal Declaration of Human Rights, the European Convention on Human Rights and its Protocols, the International Covenant on Civil and Political Rights etc.), with the obvious exception of the revised European Social Charter (from 1998) and the Treaty of Nice, from the year 2000, in which the two notions, „man” and „woman” were arbitrarily replaced by the notion of "spouses”, - have stipulated „expressis verbis" that a family is based only on the marriage between a „man” and a ,woman”,

Our legal study - with references ,ad fontes” (to the sources) offers to the reader of our paper the opportunity to become acquainted not only with the rules of "Juris romanum antiquum", but also with how international and national law have perceived and defined the institution of marriage. In fact, regarding the old Romanian Law (Jus valachicum), we have emphasized that - through "The Great Nomocanon", printed in Târgovisste in the year 1652 - it has actually reaffirmed the definition left by the famous Roman solicitor (jurisconsultus), Modestin, of „legitimate marriage”, i.e. of ,justa nuptiae”, which can only be concluded between a "man" and a „woman", hence the obligation of any civilist or constitutionalist to return to „the sources” (ad fontes), i.e. to the provisions of Roman law, of the our ancient national Laws and of the main international instruments of our time.

Keywords: the Marriage; International Law; Roman Law; the Family Institution; the Human Rights.

How to cite: Mititelu, C. (2019). About the Right to SameSex Marriage. Some Considerations and Interpretations from the Constitutional Law Perspective. Logos Universality Mentality Education Novelty: Law, 7(2), 80-88. doi:10.18662/lumenlaw/29 


\section{Introductory word}

According to the Roman jurists, "the union of a man with a woman (maris atque feminae conjugatio)" was called "Matrimonium" (marriage), and "the conceiving of children (liberorum procreatio) and their education (educatio)", by the two parents (man and woman), are justified both by "Jus naturale" (Natural law), which is "the right that all beings have learnt from nature (natura)" ("Justiniani Institutiones", LB. I, II, 2002), and by "jus civile", which was, indeed, the "specific" or "own" right of the Roman State (Gaius, Institutiones, LB. I, I, 1).

Therefore, the right to marry of persons of the opposite sex, namely between a "man" and a "woman", was stipulated by both natural law (jus naturale) and by "jus positivum", that is, by written Roman law, which also stipulated the "legal status of persons", which Gaius described using the notion of "homines" (people), regardless of the fact that they, "taken in their entirety, are either free, or slaves" (Gaius, Institutiones, LB. I, III, 9), and not of "cives" (citizens).

\section{The right to same-sex marriage}

The right to marry of persons of the opposite sex (man and woman), stipulated by "Jus naturale", is also explicitly stated in the text of the main international instruments regarding human rights and their legal protection (Dură, 2013; Dură \& Mititelu, 2012, 2015). Their "primacy character over those of national law" (Dură, 2018a) is recognized "expressis verbis" in the text of the two Constitutions, namely that of Romania (according to Art. 20) and of the Republic of Moldova (Art. 8 and 54, para. 2).

As for the rights of the "citizens" of the two States - of which the right to marry is also a part - their Fundamental law explicitly states that the "constitutional provisions" on these rights must be "interpreted and applied in accordance with the Universal Declaration of Human Rights ..." (Art. 20, para. 1, Constitution of Romania), and that they must "... base their relations with other states on the unanimously recognized principles and norms of international law" (Art. 8, para. 1, Constitution of the Republic of Moldova), on the basis of which the institution of Marriage is regulated in both countries.

In the main international instruments, such as the Universal Declaration of Human Rights (Dură, 2015) (Art. 16), the European Convention on Human Rights (Mititelu, 2015a) (Art. 12) and the International Covenant on Civil and Political Rights (Mititelu \& Mitra Radu, 
2013a) (Art. 23), whenever either principles (Dură, 2013) or legal norms regarding Marriage or Family were enunciated, only references to "man" and "woman" were indeed made, and to their status as "parents" (Dură, 2018b) in their relationship with the children, that is, the marriage which is the foundation of the family itself.

According to the provisions of the Constitution of Romania, its "citizens" "benefit from the rights and freedoms enshrined in the Constitution and other laws and have the obligations stipulated in these" (Art. 15, para. 1). In fact, the same provision can be found reproduced "ad litteram" in the text of the Constitution of the Republic of Moldova (according to Art. 15).

Among these rights - enshrined in the Constitutions and laws of the two States - we do not find the so-called same-sex marriage right. In contrast, the "equality of rights" of "man and woman", on whose "consent" marriage is based on, is explicitly stipulated in Article 48, para. 1 of the Constitution of Romania, as well as in Article 48, para. 2 of the Constitution of the Republic of Moldova.

Moreover, in the texts transmitted by "Jus romanum antiquum" and "Jus romanum novum", we find the same explanation, namely that a marriage can only be concluded between a man and a woman, who had to be "taken to the man's house" (deductio mulieris domum mariti), and that such a marriage could not be concluded in the absence of one of the two (according to Paulus, Sentences, 2, 19, 8; Ulpianus, Digestae, 50, 17, 30) (as cited by Tomulescu, 1975: 145), as only their "consent" (consensus), that is, of the two spouses, man and woman, gave the legal force inherent to this institution. In the terms of the famous Roman legal consultants, "... a marriage cannot be concluded without the consent (consensus) of the parties" (Celsus, Digestae, LB. XV) (Justinian, n.d.), that is, of a "vir" (man) and a "mulier" (woman) (Modestinus, Reguli, LB. I) (Justinian, n.d.).

\section{Provisions of the international law regarding the same-sex marriage}

In the revised "European Social Charter" (Mititelu \& Mitra Radu, 2013b) (Art. 16) - from 1996, in force since 1998 - and in the "Charter of Fundamental Rights of the European Union" (Dură \& Mititelu, 2013) (Art. 9) - from 2000 - no mention or reference was made to the sex of the partners, but two new notions were introduced, namely that of "parents" and "spouses", which replaced the two traditional notions, encountered in the Roman era until 1996/2000, namely that of "man" and "woman", hence 
the obsessive reference to the text of these two "Charters" by the people who are campaigning for same-sex marriage.

In the spirit of the provisions of the European Social Charter and the Treaty of Nice, from 2000, those who advocate for same-sex marriage have called for the "differences given by the different biological sex between father and mother" (Dănileț, 2017) to be blurred, hence the exclusive use in some legal texts only of the notion of "spouses" or "parents", without mentioning that it is a "father" and a "mother", that is, a man and a woman.

The same activists demanded that "when it comes to children's responsibilities, there should be no discrimination on the grounds of sexual orientation or gender identity ..." (Dănileț, 2017), etc. However, even one of these activists, who advocates obsessively for Same-sex marriages, had to admit that "in Europe, gay marriage is not considered a fundamental right, as the European Court of Human Rights/ECHR reserves it only for a man and a woman. As a result, "it remains up to the states to grant it to people of the same sex", but - he concluded - "the situation is different in the U.S., where the Supreme Court decided in 2015 - in the case of Obergefell et al. v. Hodges that the U.S. Constitution guarantees the right of same-sex persons to marry under conditions similar to those of the opposite sex and that states cannot reserve the right of marriage only for heterosexual couples" (Dănileț, 2017).

But, what was the situation in the U.S. until 2015? In 1868, when the fourteenth Amendment to the Constitution of the United States of America was ratified, "each state limited the meaning of marriage to the relation between a man and a woman, and no one expressed doubts as to the constitutionality of this proceeding" (US Supreme Court, 2015). It is therefore clear to everyone that it was only "viri et mulieris coniunctio" (Justiniani Institutiones, LB. I, IX, 1), that is, the "(bodily) relation between a man and a woman", also referred to by the famous Roman jurist, Modestinus (second century AD), in his classic definition given to marriage, and which "the Great Code of Laws", or "Târgovişte Code of Laws", printed in 1652, translated as suggestive as possible through the words: "the copulation of a man and a woman" (Chapter 203) ("Îndreptarea legii", 1962: 212-213).

In fact, according to the definition given by this Code of Laws of the Romanian Principalities, "The legal weddings are those done respecting the holy Code of Laws, the lawful man and the woman received by the man" (Chapter 203) ("Indreptarea legii", 1962: 212-213), as only the wedding between two young people, of the opposite sex, "... is good, as it draws the man near to God by the purity of the young boy and young girl" (Chapter 203) (“'̂ndreptarea legii”, 1962: 212). 
That is, according to the Roman jurists, only those who "... marry according to the provisions of the law: men at puberty and nubile women, ..." can say that "they conclude a lawful marriage (iustas nuptias)" ("Justiniani Institutiones", 2002, LB. I, X: 26-27).

It should be noted, however, that, on the American continent, only in 2015 the Supreme Court of the United States ruled in favor of recognizing Same-sex marriages throughout the United States. But even in the U.S. Court's decisions we find that some U.S. states, such as Michigan, Ohio, Kentucky and Tennessee, "... define Marriage as a union between a man and a woman" (US Supreme Court, 2015), and that the "officials" in these States "refuse" to solemnize a so-called same-sex marriage.

In order to be convincing, some Romanian magistrates also tell us that in "some states of the world, two people of the same sex can marry" (Dănileț, 2017), but that "in our country this is expressly forbidden. Thus, art. 258, para 1 and 4 of the Civil Code - according to them - shows that in Romania marriage takes place between a man and a woman, and art. 277 of the Civil Code explicitly prohibit same-sex marriage" (Dănileț, 2017).

Indeed, this is the reality in Romania, and as regards the fact that, in some States, same-sex marriages were allowed - following ideological, electoral pressures etc. - this cannot be a justified reason for the other States of the world or of the European Union - including Romania and the Republic of Moldova - to allow them, hence the vehement appeal of the some jurists "pro" marriage between persons of the same sex, and, ipso facto, their request for the "revision of the Constitution", "parliamentary debate", "referendum" etc.

\section{Constitutional provisions regarding the right to marriage}

But what do the Constitutions of the two states, i.e. Romania and the Republic of Moldova stipulate?! According to the Constitution of Romania, "the family is based on the freely agreed marriage between the spouses" (Art. 48, para. 1), without specifying whether they are of the same sex or of the opposite sex (man and woman). On the other hand, it stipulates "the right and duty of the parents to ensure the upbringing, education and training of children" (Art. 48, para. 1).

Therefore, as one can see, the legislature of the Country merely took over and reaffirmed the provision set out in the revised European Social Charter (from 1998) and the Treaty of Nice (2000). However, in the text of the Constitution of the Republic of Moldova we can see that the legislator actually reaffirmed the provisions set out in the main international 
instruments, i.e. the Universal Declaration of Human Rights, the European Convention on Human Rights and the International Covenant on Civil and Political Rights, including those of children (Mititelu, 2015b).

Indeed, in the Constitution of the Republic of Moldova it is stipulated "expressis verbis" that "Family is based on the freely consented marriage between man and woman" (Art. 48, para. 2), thus emphasizing the old legal principle enunciated by the Roman law and reaffirmed by the Byzantine law, according to which at the base of the family lies only "the bodily connection between a man and a woman", which - according to Christian law - can only take place after the conclusion of the contractual agreement and the solemnizing of the Wedding or Religious union, thus according to the provisions of the divine and natural law, as well as of moral (religious) law.

According to the same Romanian magistrates, "... public authorities cannot consider that homosexuality is contrary to "morality", within the meaning of Article $10 \int 2$ of the ECHR, since sexual orientation is a fundamental human right under Article 8 of the ECHR" (Dănileț, 2017).

In fact, however, the text of Article 10 of the European Convention on Human Rights explicitly refers only to the "right to freedom of expression", and it is stated that this "right encompasses the freedom of opinion and the freedom to receive or to communicate information or ideas without the mix of public authorities and without regard to borders" (Art. 10, para. 1), and not at all homosexuality.

Furthermore, in paragraph 2 of this Article (10) it is stipulated that "the exercise of these freedoms ... may be subject to formalities, conditions, restrictions or sanctions stipulated by law, which are necessary measures, in a democratic society, for ... public safety, ..., the protection of health or morality, ..." (Art. 10, para. 2).

The restrictions or sanctions provided by the European Convention, therefore, concern only the two freedoms, namely the freedom of opinion and the freedom to receive information uncensored by the public authorities, and, consequently, no allusion is made to the members of the L.G.B.T.

According to the provisions of the European Convention on Human Rights, a democratic society, as Romania is - at least constitutionally (according to Art. 1, para. 3 of the Constitution of Romania) - as a member state of the European Union - has the obligation to ensure the protection of public "health" (Art. 34, para. 1 of the Constitution of Romania) and of "public morality" (Art. 53, para. 1 of the Constitution of Romania), and "the natural person has the right to dispose of his/herself, unless they violate the 
rights and freedoms of others, public order or good morality" (Art. 26, para. 2 of the Constitution of Romania). Hence, the categorical prohibition - by the same constitutional text - of "obscene, contrary to good morality" manifestations (Art. 30, para. 7 of the Constitution of Romania) and "exploitation of minors, their use in activities that would harm their health, morality or endanger their lives or normal development" (Art. 49, para. 3 of the Constitution of Romania).

Therefore, if as a citizen of a state we do not have the obligation to respect the divine law and the natural, moral law, we do have the obligation not to violate the provisions of "public morality", "public order", and "good morality", as explicitly stipulated by the fundamental laws of the States of the world, including those of Romania and the Republic of Moldova.

\section{Instead of Conclusions}

For those who are familiar only with the provisions of the legislation of our day, - be it national, European or international, - and not with those stipulated by "Jus naturale" and Moral law, it is clear that those who claim the existence of a so-called same-sex marriage right cannot in fact rely on any legal basis, excluding, of course, the E.U. Social Charter and the Treaty of Nice.

Moreover, by requesting the official recognition of same-sex marriages, the provisions of "public morality", "public order" and "good morality" are, in fact, violated, a transgression sanctioned not only by moral Law - which it is "fons juris naturale" (the source of the natural law) - by also by the main international instruments and the legislation of some States of the world, including the fundamental laws of the two States, namely Romania and the Republic of Moldova (according to the Constitution of Romania, art. 53, para. 1; Constitution of the Republic of Moldova, art. 54, para. 2).

\section{References}

Council of Europe. (1950). European Convention on Human Rights. Retrieved from https://www.echr.coe.int/Documents/Convention_ENG.pdf

Council of Europe. (1961). European Social Charter. Retrieved from https://rm.coe.int/168006b642

Dănileț, C. (2017). Familia pe înțelesul tuturor - Partea a cincea: Familia reflectată in instrumentele privind drepturile omului (5 septembrie 2017) [Family for all - Part Five: The family reflected in human rights instruments]. Retrieved from http://www.contributors.ro/administratie/justitieordine- 
About the Right to Same-Sex Marriage. Some Considerations and ...

publica/familia-pe-in $\%$ C $8 \% 9$ Belesul-tuturor- $\%$ E2\%80\%93-partea-acincea-familia-reflectata-in-instrumentele-privind-drepturile-omului/

Dură, N. V. (2013). General principles of European Union legislation regarding the juridical protection of the human rights. Journal of Danubius Studies and Research, III (2), 7-14.

Dură, N. V. (2015). The Universal Declaration of Human Rights. 10 ${ }^{\text {th }}$ Edition of International Conference The European Integration - Realities and Perspectives. EIRP Proceedings, 10, 235-242.

Dură, N. V. (2018a). Despre caracterul prioritar al normelor dreptului internațional, privind drepturile şi libertățile fundamentale ale omului, în raport cu cele ale dreptului național [About the priority character of the norms of international law, regarding the fundamental human rights and freedoms, in relation to those of the national law]. Revista Natională de Drept, 7-9, 5458.

Dură, N. V. (2018b). Provisions of international law on the parents' right to provide their children with a religious education. The Fundamentals of Our Spirituality, X, 240-248.

Dură, N. V., \& Mititelu, C. (2012). Human rights and their universality. From the rights of the ,individual" and of the „citizen" to „human” rights. Exploration, Education and Progress in the third Millennium, I (4), 103-127.

Dură, N. V., \& Mititelu, C. (2013). The Treaty of Nice, European Union Charter of Fundamental Rights. In A. C. Puşcă, V. Negruț, I. Savenco, Ş. Gheorghe, F. M. Nuţă, A. C. Nuţă, M. Arsith (Eds.), The European Integration - Realities and Perspectives Proceedings (pp. 123-129). Retrieved from https://pdfs.semanticscholar.org/eedd/73906b5a4bbf0ba6d243e69bbcb52 9b2b66a.pdf?_ga $=2.124727240 .338626027 .1578476498$ 1215171703.1564393149

Dură, N. V., \& Mititelu, C. (2015). The human fundamental rights and liberties in the text of some Declarations of the Council of Europe. Exploration, Education and Progress in the third Millennium, I(5), 7-22.

Indreptarea legii 1652 [Law enforcement]. Bucharest, Romania: Editura Academiei RSR; 1962. 212-213.

Justinian. (n.d.). Digestae. LB. XXIII, 2, 1; 22. Retrieved from https://droitromain.univ-grenoble-alpes.fr/Corpus/digest.htm

Justiniani Institutiones. (2002). Bucharest, Romania: Lumina Lex.

Mititelu, C. (2015a). The European Convention on Human Rights. 10 ${ }^{\text {th }}$ Edition of International Conference The European Integration - Realities and Perspectives. EIRP Proceedings, 10, 243-252.

Mititelu, C. (2015b). The children's rights. Regulations and rules of international law. Ecumeny and Law, 3, 151-169. 
Mititelu, C., \& Mitra Radu, M. (2013a). International Covenant on Civil and Political Rights. Journal of Danubius Studies and Research, III(2), 47-57.

Mititelu, C., \& Mitra Radu, M. (2013b). The European Social Charter (Revised) and the Protection of the Human Rights. Ovidius University Annals, Economic Sciences Series, XIII (1), 1593-1598.

Republic of Moldova Parliament. (1994). Republic of Moldova Constitution. Republished. Monitorul Oficial, 78, 2016, March 29.

Romanian National Assembly. (1991). Romanian Constitution. Republished. Monitorul Oficial al României, 767, 2003, October 31.

Tomulescu, C. (1975). Drept privat roman [Roman private law]. Bucharest, Romania: Tipografia Universității din București.

United Nations General Assembly. (1948). Universal Declaration of Human Rights. Retrieved from https://www.un.org/en/udhrbook/pdf/udhr_booklet_en_web.pdf

United Nations General Assembly. (1966). International Covenant on Civil and Political Rights. Retrieved from https://en.wikipedia.org/wiki/International_Covenant_on_Civil_and_Poli tical_Rights

US Supreme Court. (2015). Opinia Curții Supreme a SUA în privința căsătoriilor dintre persoanele de același sex [US Supreme Court opinion on same-sex marriages].

Retrieved from http: / $/$ www.constcourt.md/libview.php?l=ro\&idc $=9 \& i d=676 \& \mathrm{t}=/$ Media /Publicatii/Opinia-Curtii-Supreme-a-SUA-in-privinta-casatoriilor-dintrepersoanele-de-acelai-sex/ 